\title{
MIDWEST INDIANS AND FRONTIER PHOTOGRAPHY
}

\author{
by JOHN R. Vincent
}

Curator of the Sanford Museum, Cherokee, Iowa

Photography is a hobby enjoyed by millions of enthusiasts thanks to our modern equipment and development processes. A hundred years ago, however, few people were sufficiently interested or had enough persistence to learn the difficult techniques involved in taking successful photographs. The most common photographic process used in the period following the Civil War was the "wet plate" process, wherein a glass plate coated with chemicals was used in a wet state to record the image. The wet or prepared plate was extremely delicate and subject to many accidents. The plate could not be touched without leaving a mark or exposed to dust without becoming "freckled." Drying winds or freezing temperatures made the use of these unstable plates impossible. Perhaps more important is the fact that in many cases the early photographer had to construct his own dark room, secure and mix his chemicals and go through the complicated development procedure under extremely primitive conditions.

As a consequence, photographs of Indians from the Iowa area taken before 1880 are rare. A close examination of surviving examples provides a wealth of information concerning Indians in Iowa as they appeared during a period of rapid cultural change and also provide clues to their prehistoric appearance and activities.

The Sauk and Fox seem at first glance to be the most important Indians to occupy the Iowa area. However, archaeological evidence and the earliest chronicles indicate that these groups were relative newcomers to the area. The Sauk originally occupied land in what is now a large part of Wisconsin and Illinois. The Chippewa, aided by the French, forced the Sauk out of Wisconsin and into central Illinois. As a result of the Blackhawk War in 1832 and due to extreme pressure by white settlers, the Sauk abandoned their land east of the Mississippi River and joined the Fox who were already established in central Iowa. In 1842 the Sauk and Fox gave up their 
land in Iowa for tracts in Kansas which were again exchanged for land in Oklahoma.

Figure 1 is a portrait of Kryo'Kaga, known as Keokuk. The photograph is from a daguerreotype made in 1847. Keokuk, a controversial figure, was appointed chief of the Sauk after the Blackhawk uprising.

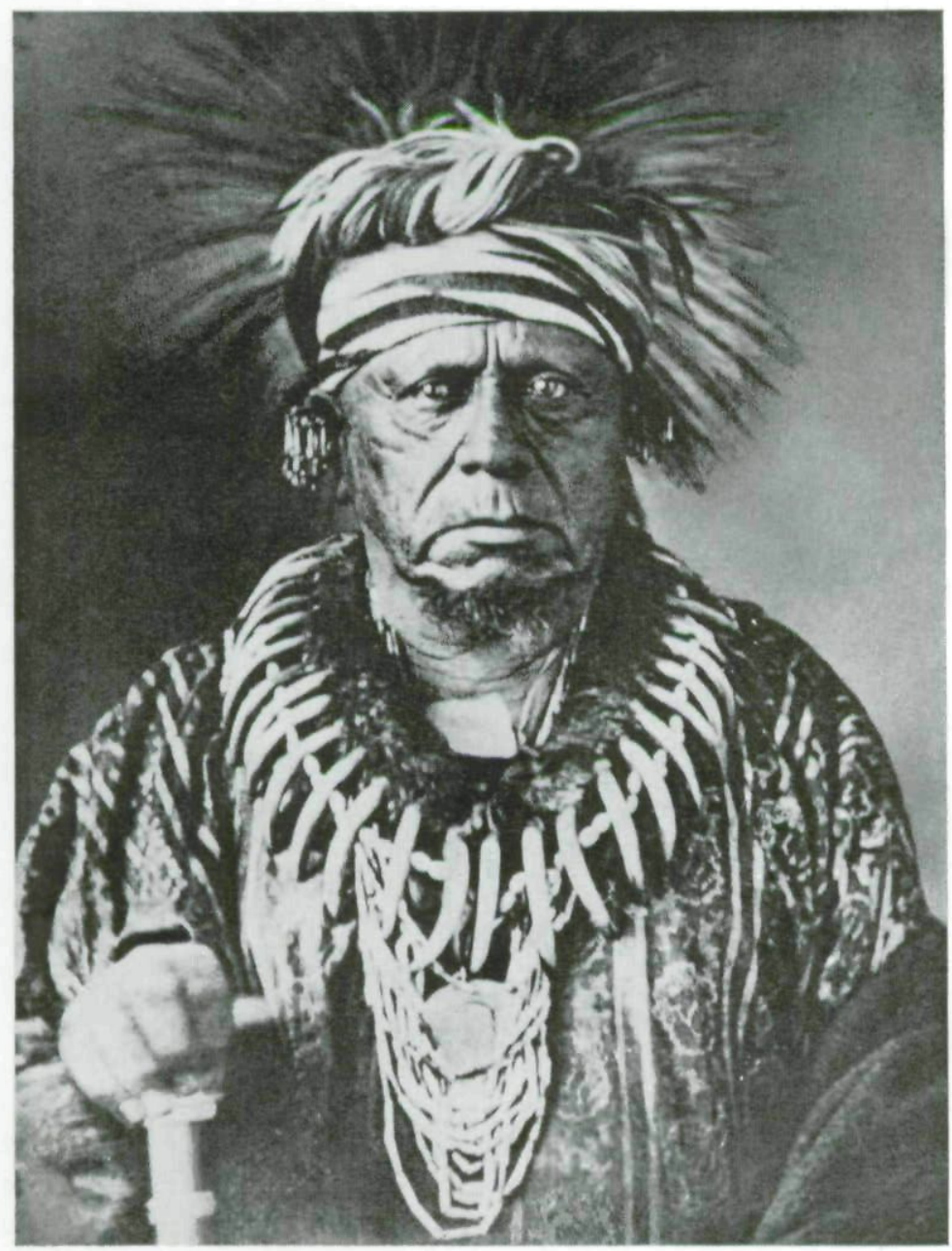

Smithsonian Institute, Bureau of American Ethnology Fig 1 Kryo'Kaga, or "One who moves about alert" 
The Fox Indians were driven out of Michigan by the Chippewa Indians and French during the years 1729-1733. Assisted by the Sauk, they displaced the Illinois Indians from the Rock River area of what is now Illinois. In the early 19th century they left their allies, the Sauk, and settled in central Iowa. In 1832 the Sauk took refuge with the Fox after the Blackhawk War and the two groups sold their holdings in Iowa and moved to land in Kansas. The two groups again separated and the Fox purchased land near Tama, Iowa, where they live today.

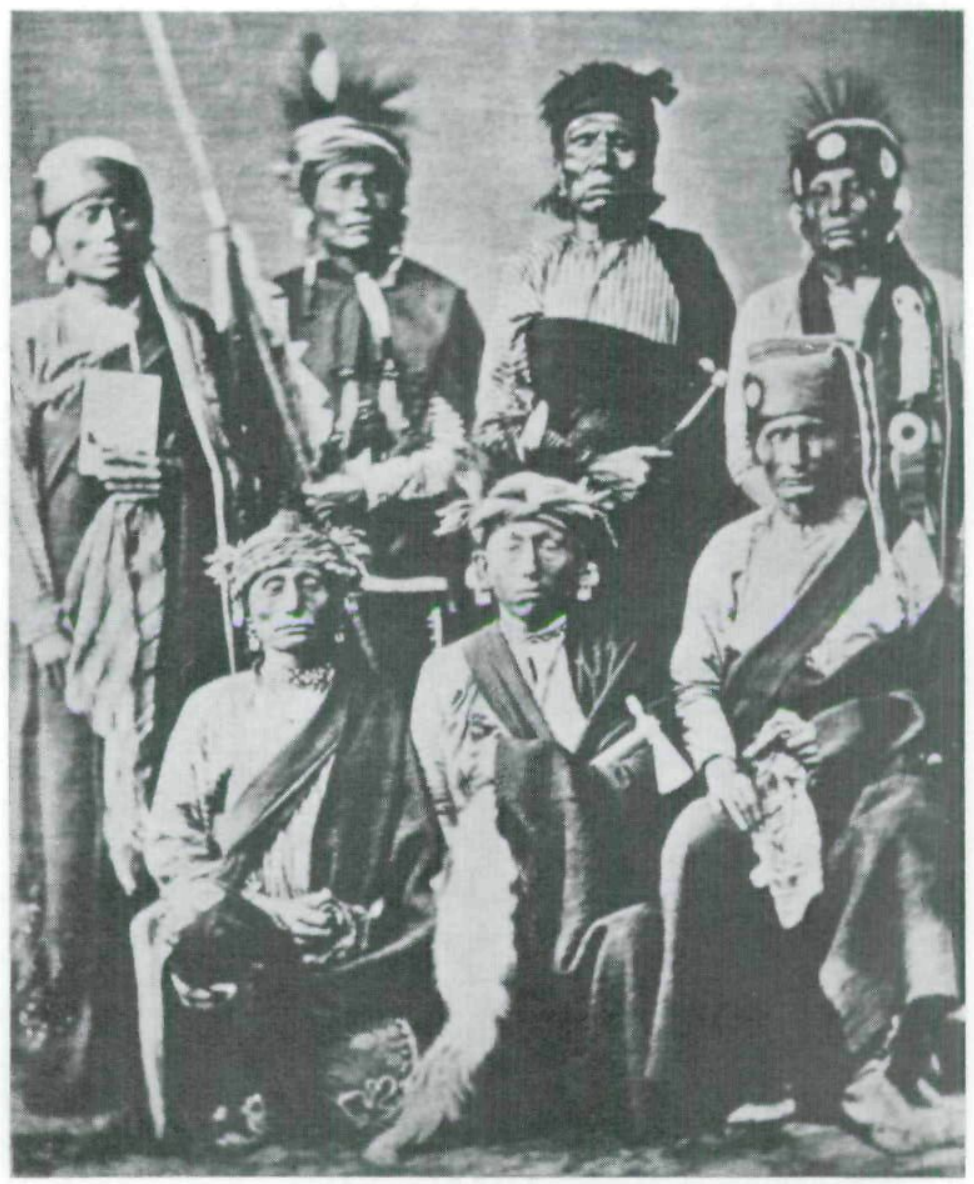

Smithsonian Institute, Bureau of American Ethnology

Fig. 2 Group of Fox Chiefs 
Figure 2 shows a group of Fox chiefs who were part of a delegation to Washington, D.C. in 1869. Typical head dresses are in evidence, as the yarn turban with a deer hair roach or the bearskin cap with a single feather.

The Iowa Indians originally inhabited most of the state named for them and ranged widely within its general borders before settling on the Des Moines River. After several bitter defeats at the hands of the Sauk and Fox and difficulties with the Omaha and Dakota they were allotted lands in Western Iowa and Eastern Nebraska in the Platt Purchase of 1814, but by 1836 they retained only a small reservation in Nebraska. Figure 3 shows a delegation of Iowas in 1862 . The photograph includes British, Knife, Deer Thigh, Little Chief, and several government officials. There is a striking similarity between the head dresses and ornaments of the Sauk, Fox, Iowa, and Missouri.

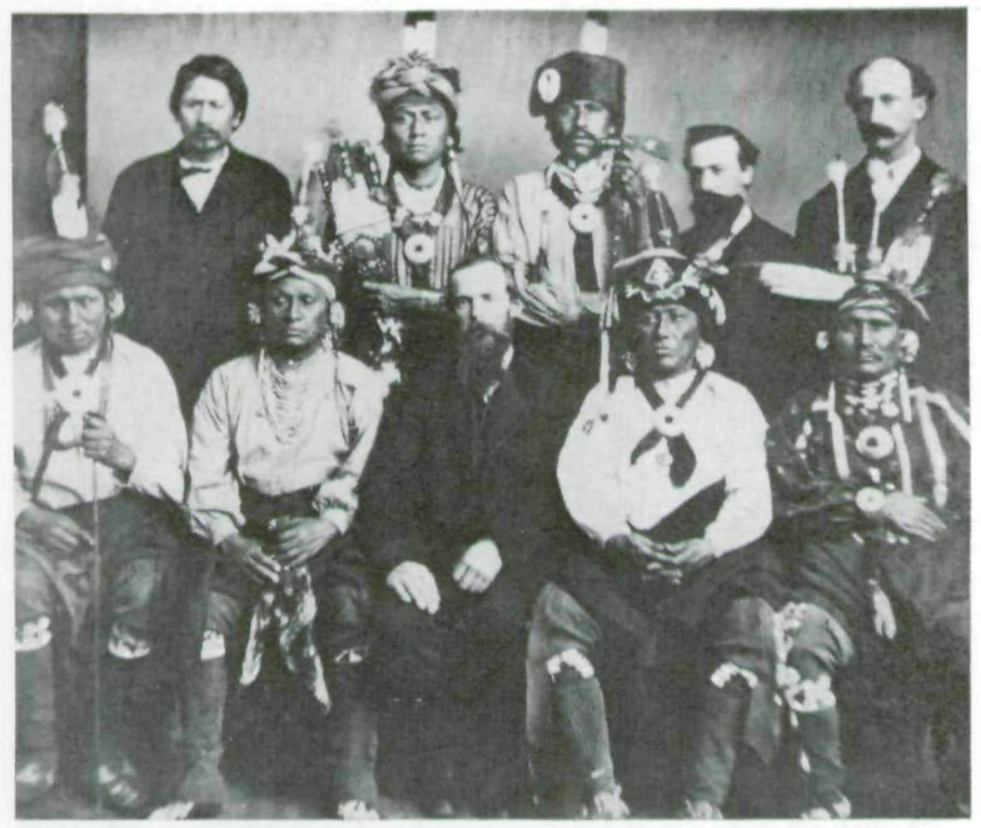

Fig. 3 Group of Iowa

Smithsonian Institute, Bureau of American Ethnology 
The French first made contact with the Potawatomi Indians living in the lower Michigan peninsula. The Potawatomi moved southward from Michigan into the Chicago area, displacing the Illinois Indians about 1765. They allied themselves first with the French and later with the English during the War of 1812. White expansion had crowded them across the Mississippi by 1841 . The tribe divided with one group ultimately receiving a reservation in Southeast Iowa. These were called Prairie Potawatomi. In 1846 they disposed of their land and moved to Kansas. Early population estimates for all Potawatomi indicate 2,500 persons; however, a 1908 count lists 676 Prairie Potawatomi in Kansas.

Figure 4 shows two Potawatomi chiefs outside a typical plains tepee. If the Potawatomi were woodland Indians like the Sauk and Fox, this photo would indicate that they had apparently adopted plains-type clothing and housing after moving to Kansas.

The maps of the Marquette expedition indicate that in 1673 the Oto Indians were occupying land some distance up the Des Moines River. They moved to the Missouri River, somewhere near the mouth of the Grand River, and ranged widely east and westward but eventually returned to this general area. Through the treaties made in 1803 and 1836 they and the Missouri released all claim to their holdings in Iowa and Missouri and occupied land in Kansas.

Figure 5 is of Arkeketah, or "Stands by it," who was chief of the Oto in 1874.

The Missouri Indians occupied an area on the lower reaches of the river named for them. Their estimated population was 1,000 persons in 1780. Repeated wars with the Sauk and Fox and a severe small pox epidemic reduced their number greatly. After another unfortunate war with the Osage Indians in Kan- 
sas, they joined the Otos. By 1805 the combined Oto and Missouri population was placed at 300 .

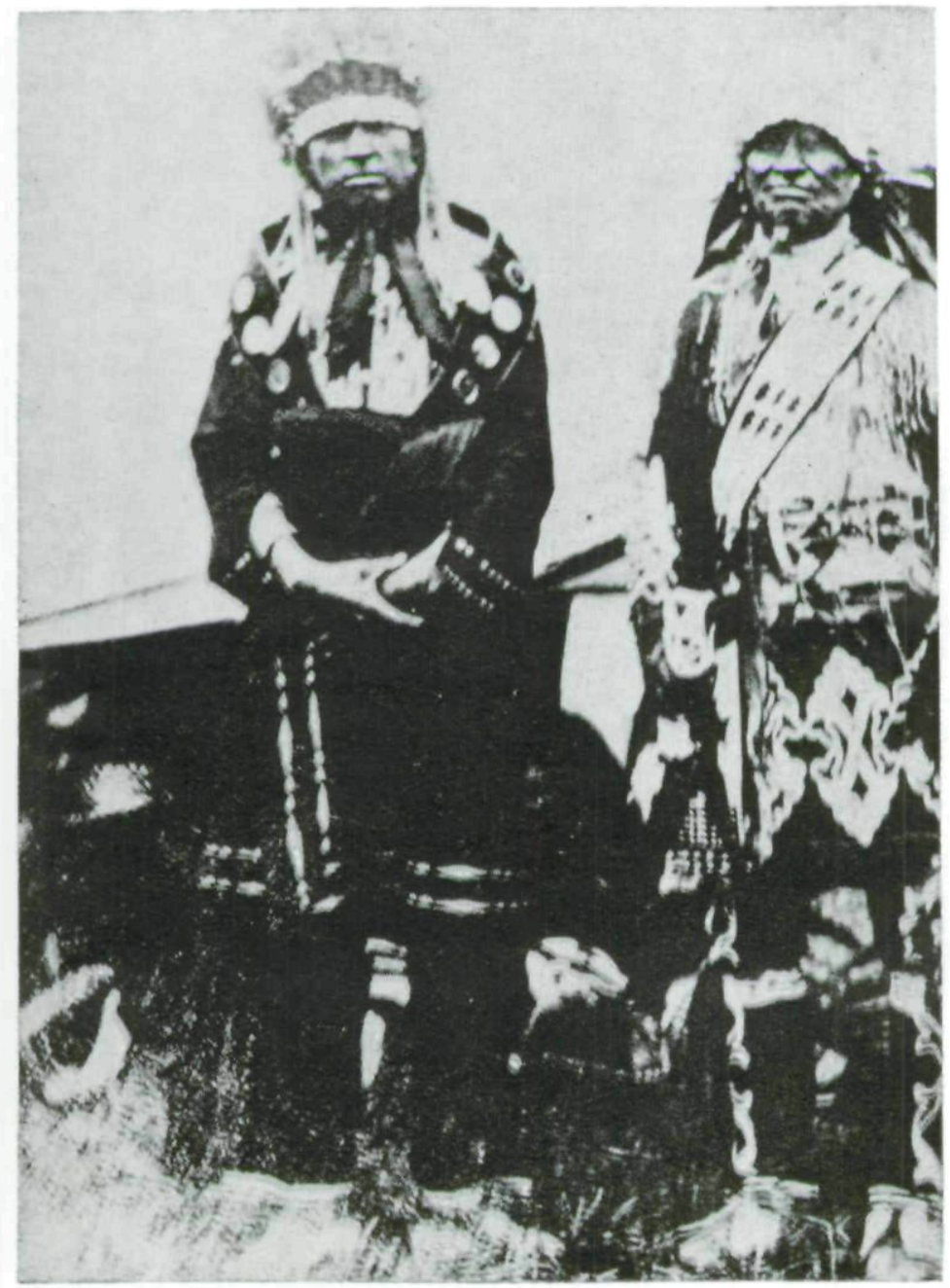

Fig. 4 Prairie Potawatomi

Denver Art Museum 
Figure 6 is of Trache-che, or "True Eagle," who was chief of the Missouri from 1860 to 1874 . In this photograph he wears the otter fur and grizzly bear claw necklace so common to Sac, Fox, and Missouri leaders.

A strong tradition among the Omaha indicates that they were part of a group living near the Ohio and Wabash Rivers.

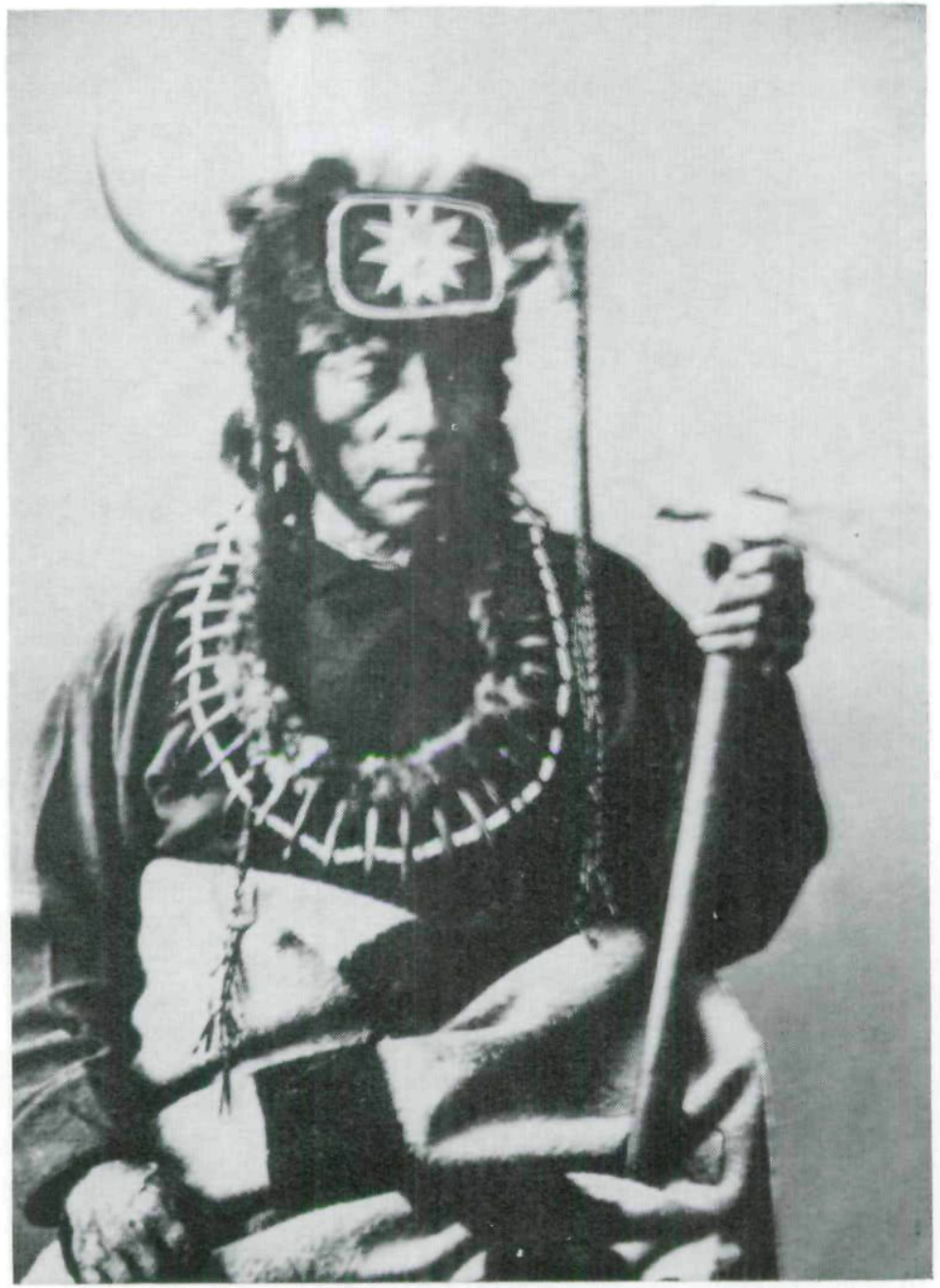

Smithsonian Institute, Bureau of American Ethnology

Fig. 5 Arkeketah, or "Stands by It" 


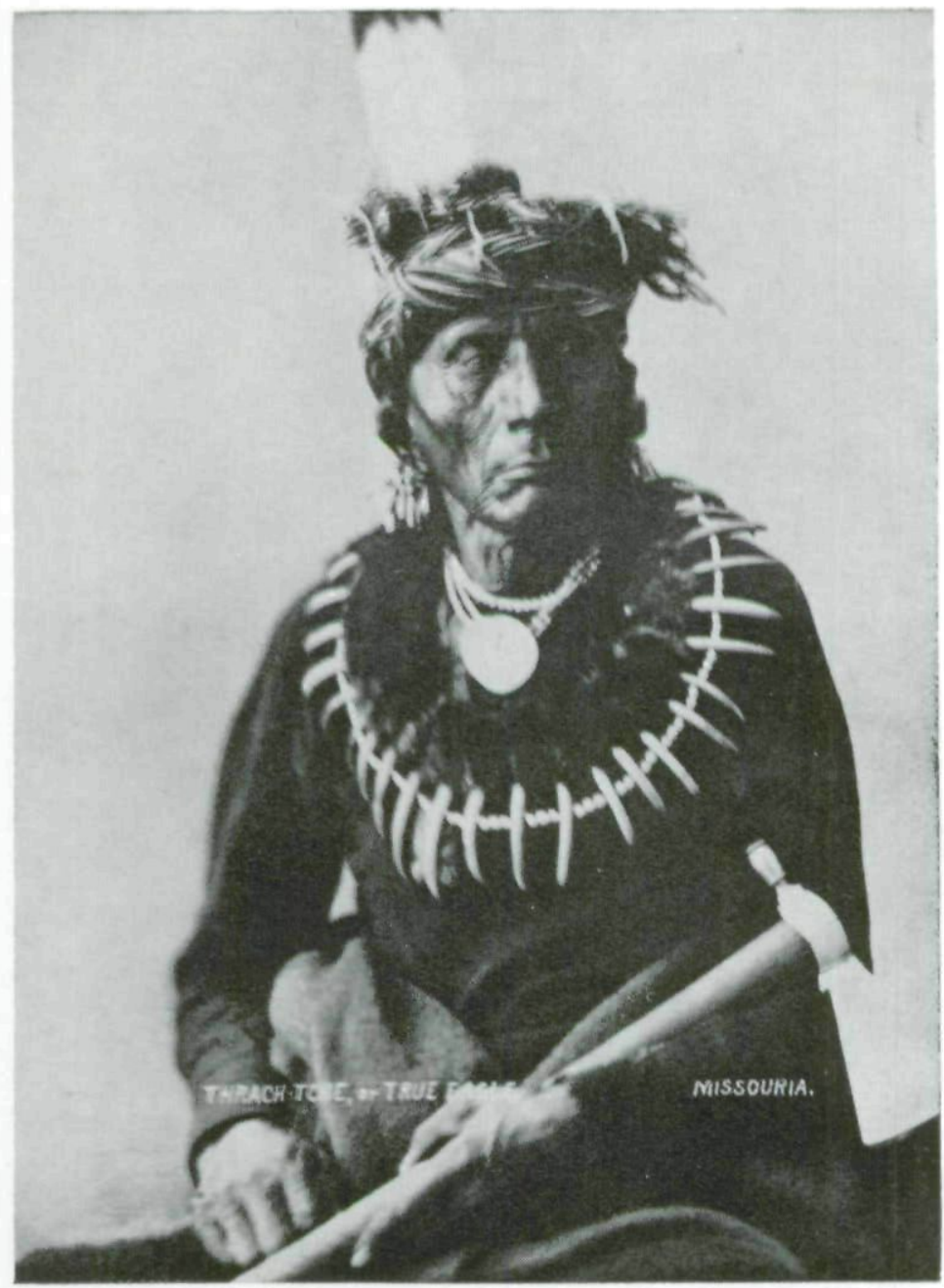

Smithsonian Institute, Bureau of American Ethnology Fig 6. Thrache-che, or "True Eagle"

This group apparently moved down the Mississippi River and as far inland as Pipestone, Minnesota. Pressure from the Dakota Indians forced them into South Dakota and Nebraska where they occupied land between the Platt and Niobrara Rivers. Their population fluctuated radically with the ravages of small pox, and fell from an estimated 2,800 in 1780 to 300 in 1805 . 
The interesting personalities among the Indian tribes of the area was not limited to men. Figure 7 is of "Betsy," a well known woman among the Omaha who participated in the annual buffalo hunts, riding with the men. She was apparently well-educated and spoke three Indian languages as well as French and English.

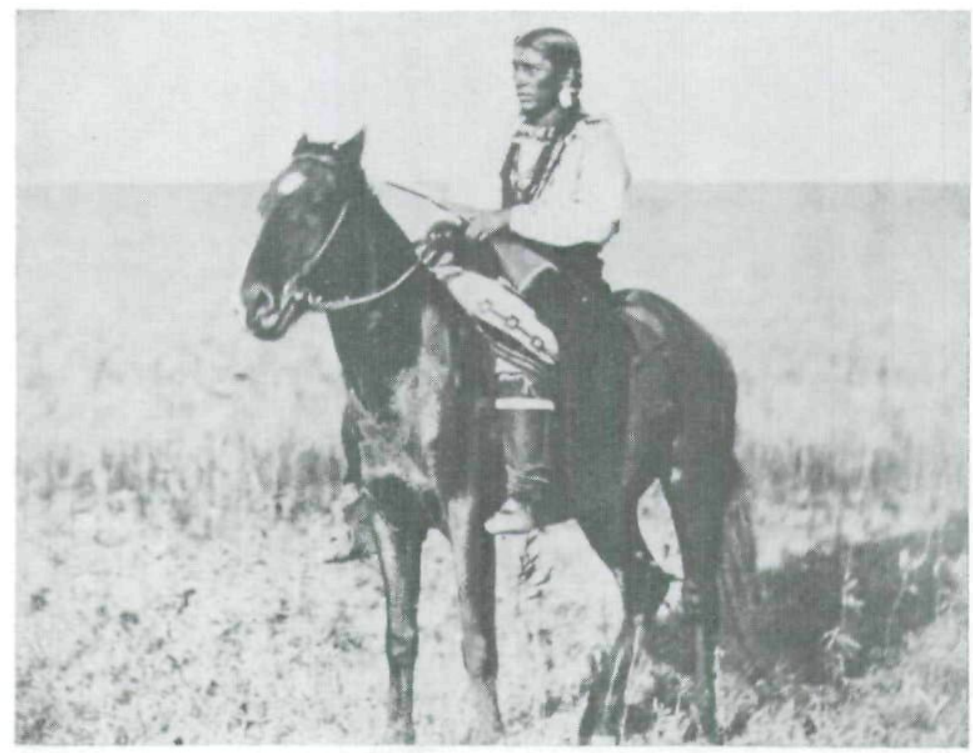

Fig. 7 "Betsy"

Miller Studio, Pierre, South Dakota

White explorers first made contact with the Dakota when they lived as woodland Indians in what is now part of Minnesota, Iowa, Wisconsin, and North and South Dakota. Pressure from the Chippewa further east caused the Dakota to move westward toward the plains, and by 1750 groups of Dakota Indians were traveling across the Missouri River and into the Black Hills. The acquisition of the horse and a buffalo hunting economy provided added impetus to this westward movement. After the Minnesota uprising in 1862, they lost all rights to land east of the Missouri River and were taken to reservations further west in North and South Dakota and Nebraska. Their further resistance to white population pressure precipitated the battle of the Little Bighorn in 1876 and the Battle of Wounded 
Knee in 1890. Early population estimates indicate there were approximately 2,500 Dakota in the seven separate bands. Today members of the tribe live on reservations in Minnesota, Nebraska and North and South Dakota.

Figure 8 is of Ite-o-maga-ju, or "Rain in the Face," and his youngest wife.

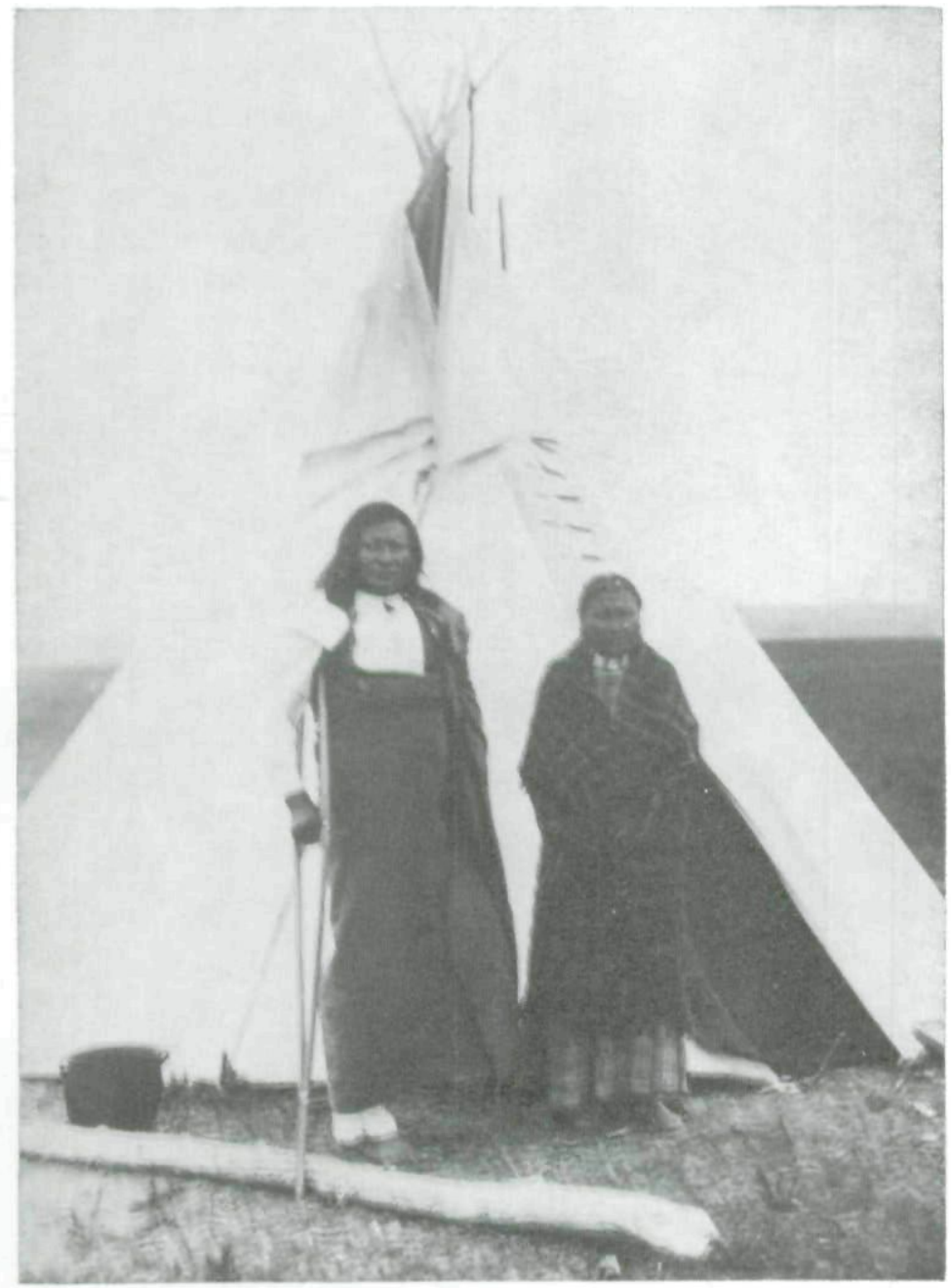

Denver Public Library, Western Collection Fig. 8 Ite-o-maga-ju, or "Rain in the face" 
Copyright of Annals of Iowa is the property of State of Iowa, by \& through the State Historical Society of Iowa and its content may not be copied or emailed to multiple sites or posted to a listserv without the copyright holder's express written permission. However, users may print, download, or email articles for individual use. 